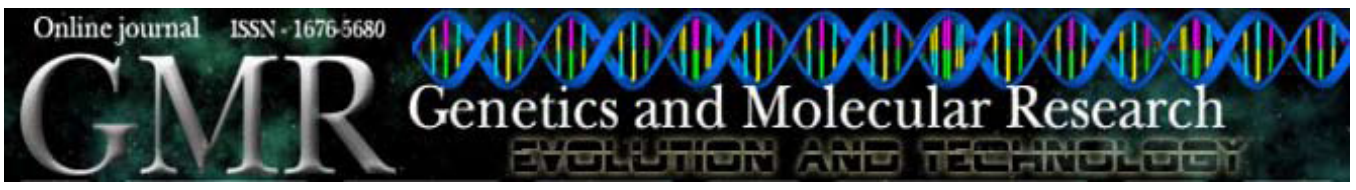

\title{
Pathogenicity for onion and genetic diversity of isolates of the pathogenic fungus Colletotrichum gloeosporioides (Phyllachoraceae) from the State of Pernambuco, Brazil
}

\author{
M.X. Vila Nova ${ }^{1}$, L.R. Borges ${ }^{2}$, A.C.B. de Sousa ${ }^{1}$, B.T.R.V. Brasileiro ${ }^{3}$, \\ E.A.L.A. Lima ${ }^{1}$, A.F. da Costa ${ }^{2}$ and N.T. de Oliveira ${ }^{1}$ \\ ${ }^{1}$ Departamento de Micologia, Universidade Federal de Pernambuco, \\ Recife, PE, Brasil \\ ${ }^{2}$ Empresa Pernambucana de Pesquisa Agropecuária, Recife, PE, Brasil \\ ${ }^{3}$ Centro de Ciências Biológicas e Saúde, Universidade Católica de Pernambuco, \\ Recife, PE, Brasil \\ Corresponding author: M.X. Vila Nova \\ E-mail: meiriana_vilanova@yahoo.com.br
}

Genet. Mol. Res. 10 (1): 311-320 (2011)

Received October 8, 2010

Accepted November 26, 2010

Published February 22, 2011

DOI 10.4238/vol10-1gmr1014

\begin{abstract}
Onion anthracnose, caused by Colletotrichum gloeosporioides, is one of the main diseases of onions in the State of Pernambuco. We examined the pathogenicity of $15 \mathrm{C}$. gloeosporioides strains and analyzed their genetic variability using RAPDs and internal transcribed spacers (ITS) of the rDNA region. Ten of the strains were obtained from substrates and hosts other than onion, including chayote (Sechium edule), guava (Psidium guajava), pomegranate (Punica granatum), water from the Capibaribe River, maracock (Passiflora $\mathrm{sp}$ ), coconut (Cocus nucifera), surinam cherry (Eugenia uniflora), and marine soil; five isolates came from onions collected from four different regions of the State of Pernambuco and one region of the State of Amazonas. Pathogenicity tests were carried out using onion leaves and bulbs. All strains were capable of causing disease in leaves,
\end{abstract}


causing a variable degree of lesions on the leaves; four strains caused the most severe damage. In the onion bulb tests, only three of the above strains caused lesions. Seven primers of arbitrary sequences were used in the RAPD analysis, generating polymorphic bands that allowed the separation of the strains into three distinct groups. The amplification products generated with the primers ITS1 and ITS4 also showed polymorphism when digested with three restriction enzymes, DraI, HaeIII and MspI. Only the latter two demonstrated genetic variations among the strains. These two types of molecular markers were able to differentiate the strain from the State of Amazonas from those of the State of Pernambuco. However, there was no relationship between groups of strains, based on molecular markers, and degree of pathogenicity for onion leaves and bulbs.

Key words: Allium cepa; Anthracnose; Molecular markers

\section{INTRODUCTION}

Brazil is one of the largest onion producers in the world. The main crops are found in the Northeast, South and Southeast regions of the country, represented by the States of Pernambuco, Santa Catarina, Rio Grande do Sul, São Paulo, and Paraná (Barbosa, 2001). In the Northeast region, crops are grown throughout the year in the São Francisco Valley, mainly in the municipalities of Petrolina, Petrolândia and Jatobá. At these localities, production is rather extensive and generates both direct and indirect jobs (IBGE, 1999). Leaf anthracnose causes major problems in onion crops in the State of Pernambuco and other regions of the country (Maranhão et al., 1997). In Brazil, the pathogen of onion anthracnose is the fungus Colletotrichum gloeosporioides, which exhibits considerable morphological and pathological variation, yet poorly understood at the genetic level (Assunção et al., 1999). Molecular techniques are useful tools for studies of phylogeny and intraspecific genetic variations, and may provide essential information, especially for the comprehension of pathogen-host relationships for phytopathogenic fungi and further aid in the process of control and regulation of plant pathology guidelines (Azevedo, 1998; Stummer et al., 2000).

Several molecular techniques have been applied to the study of phytopathogenic fungi, including the random amplified polymorphic DNA (RAPD) technique based on polymerase chain reaction (PCR) (Martinez-Culebras et al., 2002; Afanador-Kafuri et al., 2003; Franck and Jha, 2006; Cenkci et al., 2009). The PCR technique may also be used to analyze regions of the internal transcribed space of ribosomal DNA (ITS, internal transcribed spacer), thus allowing studies of different genera and species of fungi (Fungaro, 2000; Abang et al., 2002; Martinez Culebras et al., 2003; Djadid et al., 2006). ITS1 and ITS2 within the nuclear ribosomal DNA region have become very popular targets for addressing taxonomic issues among anophelines. The nucleotide sequence of these spacer regions are often much more polymorphic between species than within species (Manonmani et al., 2001; Djadid et al., 2006).

This study aimed to evaluate the pathogenicity in onion and the genetic diversity of 14 isolates of C. gloeosporioides, collected from different localities in the State of Pernambuco. 


\section{MATERIAL AND METHODS}

Fifteen isolates were used; 14 from the State of Pernambuco and one from the State of Amazonas (Table 1).

\begin{tabular}{lll}
\multicolumn{2}{c}{ Table 1. Origin of Colletotrichum } & gloeosporioides isolates deposited at Micoteca URM, Recife, Pernambuco, Brazil. \\
\hline Voucher & Place of origin & Substrate/host \\
\hline 4626 & Brejão/PE & Peduncle of onion plant (Allium cepa) \\
4627 & Vale do São Francisco/PE & Leaf of onion plant \\
4628 & Brejão/PE & Inflorescence of onion plant \\
4629 & Petrolina/PE & Leaf of onion plant \\
2018 & IPA/PE & Allium sp \\
2543 & Amazonas & Chayote (Sechium edule) \\
2547 & IPA/PE & Guava (Psidium guajava) \\
2334 & IPA/PE & Pomegranate (Punica granatum) \\
2335 & IPA/PE & Guava \\
2336 & IPA/PE & Surinam cherry (Eugenia uniflora) \\
3923 & IPA/PE & Water from Capibaribe River, PE \\
3882 & IPA/PE & Maracock (Passiflora sp) \\
2980 & IPA/PE & Marine soil \\
2680 & IPA/PE & Maracock \\
2060 & IPA/PE & Coconut (Cocus nucifera) \\
\hline
\end{tabular}

Two pathogenicity experiments were conducted. One was performed using onion leaves, in a greenhouse, and the other with onion bulbs.

\section{Two pathogenicity experiments in a greenhouse}

For the pathogenicity test in leaves, spores formed from $C$. gloeosporioides cultures incubated for 7 days at $28^{\circ} \mathrm{C}$ were used. These were counted in a Neubauer chamber, yielding a final concentration of $10^{6}$ conidia/mL. Twenty-day-old plants from the susceptible cultivar Texas Early Grano 502 were sprayed with ca. $2.5 \mathrm{~mL}$ of the spore suspension, and the plant pots were kept inside a moist chamber for $24 \mathrm{~h}$. Experimental design was entirely randomized and constituted four repetitions, each with six plants. Control consisted of identically treated plants, all of which were irrigated with only distilled water. Pathogenicity was evaluated on the third, sixth, ninth, and twelfth days after inoculation, based on the appearance of typical symptoms of leave anthracnose, and then proceeding to the re-isolation of the pathogen. The severity of the disease was estimated on a grading scale, varying from 0 to 4 according to Table 2 .

Table 2. Grading scale used for evaluation of the pathogenicity of Colletotrichum gloeosporioides isolates in onion plants.

\begin{tabular}{ll}
\hline Grade & Symptoms \\
\hline 0 & Absence of symptoms \\
1 & One leaf with symptoms and signs of disease \\
2 & Two leaves with symptoms and signs of disease \\
3 & Three leaves with symptoms and signs of disease \\
4 & Collapse and death of the plant \\
\hline
\end{tabular}

\section{Two pathogenicity experiments in bulbs}

In the second experiment, onion bulbs from the same cultivar were initially 
rinsed with water and disinfested by immersion in a $15 \%$ sodium hypochlorite solution. Mycelium-agar discs (5 $\mathrm{mm}$ in diameter) were taken from 4-day-old C. gloeosporioides colonies and transferred to the intact surface of the onion bulb, to which they adhered with the help of adhesive tape. The control consisted of equally treated bulbs, using only the agar discs. The bulbs were kept inside a moist chamber for $24 \mathrm{~h}$. For this purpose, plastic bags, previously moistened with sterilized distilled water, were maintained under ambient luminosity and temperature. Experimental design was entirely randomized and consisted of ten repetitions for each isolate. Pathogenicity was evaluated by measuring the diameter of the lesions on the onion bulbs $24 \mathrm{~h}$ after application of the phytopathogen, followed by its re-isolation. The severity of the disease was estimated according to the grading scale presented in Table 3 and through calculation of the disease index according to Mackinney (1923).

\begin{tabular}{lll}
\multicolumn{2}{l}{ Table 3. Grading scale used for evaluation of the pathogenicity of Colletotrichum gloeosporioides isolates in onion bulbs. } \\
\hline Grade & Behavior & Classification of the isolates \\
\hline 0 & Absence of lesions & Non-pathogenic \\
1 & Lesions from 1 to $5 \mathrm{~mm}$ & Weakly pathogenic \\
2 & Lesions from 6 to $15 \mathrm{~mm}$ & Mildly pathogenic \\
3 & Lesions from 16 to $25 \mathrm{~mm}$ & Pathogenic \\
4 & Lesions over $25 \mathrm{~mm}$ & Highly pathogenic \\
\hline
\end{tabular}

\section{Amplification of DNA for RAPD analysis}

Total genomic DNA extraction for each isolate was performed according to Raeder and Broda (1985). For RAPD, primers from the OPA, OPX and OPW kits were used (Operon Technologies). Amplification reactions were performed in a total volume of $25 \mu \mathrm{L}$ containing 20 to $25 \mathrm{ng}$ DNA, $0.4 \mu \mathrm{mol}$ of each primer separately, $3.0 \mathrm{mmol} \mathrm{MgCl}_{2}, 1 \mathrm{U}$ Taq DNA polymerase and enzyme buffer solution ( $20 \mathrm{mM}$ Tris- $\mathrm{HCl}, \mathrm{pH} 8.4,50 \mathrm{mM} \mathrm{KCl})$. Amplification cycles consisted of an initial denaturation $\left(5 \mathrm{~min}\right.$ at $92^{\circ} \mathrm{C}$ ), followed by 40 cycles consisting of $1 \mathrm{~min}$ at $92^{\circ} \mathrm{C}, 1 \mathrm{~min}$ and $30 \mathrm{~s}$ at $39^{\circ} \mathrm{C}$, and $2 \mathrm{~min}$ at $72^{\circ} \mathrm{C}$, followed by a final extension phase of $5 \mathrm{~min}$ at $72^{\circ} \mathrm{C}$. The amplification products were separated on a $1.4 \%$ agarose gel. Electrophoresis was in $1 \mathrm{X}$ TBE (Tris-borate-EDTA) running buffer, $\mathrm{pH} 8.0$, at $3 \mathrm{~V} / \mathrm{cm}$. The gels were stained with a solution of ethidium bromide, and then visualized and photographed using a UV transilluminator. $\lambda$ phage DNA, cleaved with HindIII enzyme, was used as a molecular weight marker.

\section{Amplification of DNA regions ITS1, ITS2 and 5.8S rDNA}

The primers ITS1 (5'-TCCGTAGGTGAACCTCCG-3') and ITS4 (5'-TCCTCCGCTTAT TGATATGC-3') (White et al., 1990) were used for amplification of DNA regions ITS1, ITS2 and 5.8S rDNA subunit. A final reaction volume of $25 \mu \mathrm{L}$ contained $50 \mathrm{mM}$ buffer solution (20 mM Tris- $\mathrm{HCl}$, pH 8.4, $50 \mathrm{mM} \mathrm{KCl}), 1.5 \mathrm{mM} \mathrm{MgCl}, 0.2 \mathrm{mM}$ dNTP, 12.5 pmol of each primer, $1.25 \mathrm{U}$ Taq DNA polymerase and $50 \mathrm{ng}$ DNA. The amplification of ITS-rDNA regions was performed in an MJ Research thermocycler. It was programmed to conduct an initial denaturation of $4 \mathrm{~min}$ at $95^{\circ} \mathrm{C}$, followed by 40 cycles consisting of $1 \mathrm{~min}$ at $92^{\circ} \mathrm{C}, 1 \mathrm{~min}$ at $55^{\circ} \mathrm{C}$ and $2 \mathrm{~min}$ at $72^{\circ} \mathrm{C}$, and an additional 5-min final extension period at $72^{\circ} \mathrm{C}$. The products of ITS1-5.8S-ITS2 rDNA loci amplification were separated on a 
$1.0 \%$ agarose gel. Electrophoresis was in $1 \mathrm{X} \mathrm{TBE}, \mathrm{pH} 8.0$, at $3 \mathrm{~V} / \mathrm{cm}$. The gel was stained in ethidium bromide solution, visualized with a UV transilluminator and photographed. A 100-bp molecular weight marker was used (Invitrogen Life Technologies). Enzymatic digestion of the amplification fragments was carried out by mixing $4 \mu \mathrm{L}$ of the amplification products of the rDNA ITS regions with $16 \mu \mathrm{L}$ of the restriction mix, containing $0.1 \mathrm{U}$ of the restriction enzyme in a specific restriction buffer solution.

\section{Analysis of restriction enzymes}

After a 2-h incubation at $37^{\circ} \mathrm{C}$ with each of the three restriction enzymes separately, DraI, HaeIII and MspI (Invitrogen Life Technologies), the fragments obtained were separated on a $1.4 \%$ agarose gel, with electrophoresis in $1 \mathrm{X} \mathrm{TBE}, \mathrm{pH} 8.0$, at $3 \mathrm{~V} / \mathrm{cm}$. A 100-bp molecular weight marker was used. Restriction fragments were stained in ethidium bromide solution for 30 min, visualized with a UV transilluminator and photographed.

\section{Analysis of amplification}

The NTSYS.PC software (Numerical Taxonomy System, Applied Biostatistics, Inc.) (Rholf, 1988) was used for the analysis of RAPD data. The data (band presence or absence) was analyzed as a binary matrix, from which a similarity matrix was built using the Jaccard coefficient. Data from the similarity matrix were used to produce a dendrogram, using the unweighted pair group method with arithmetic mean (UPGMA).

\section{RESULTS AND DISCUSSION}

The first symptoms of leaf anthracnose in the susceptible cultivar Texas Early Grano 502 appeared by the third day after inoculation. Initially, they manifested as mildly depressed lesions, followed by leaf color change and lesions arranged as concentric whirls, over which the pathogen's acervuli, covered with conidia, eventually developed. By the last evaluation, shriveling of the leaves and death of the plants were observed. Leaf elongation was observed during the evaluation of the inoculated plants in the greenhouse. According to Assunção et al. (1999), these symptoms are commonly seen in production fields, not in a greenhouse. The disease indexes are displayed in Table 4. All C. gloeosporioides isolates were pathogenic, although varying as to the degree of pathogenicity. Four groups with significant differences in disease index were determined. The first group contains a single isolate, 4627 (onion leaf/Vale do Rio São Francisco-PE), with a disease index of 100\%. The second group comprises four isolates, 4626 (peduncle/Brejão-PE), 4629 (onion leaf/Petrolina-PE), 4628 (onion inflorescence/Brejão-PE), and 2543 (S. edule/AM), exhibiting disease indexes of 42.27, 34.33, 28.81, and $14.70 \%$ respectively. The third group is composed of four isolates, 2980 (marine soil-PE), 2018 (Allium sp-PE), 2335 (P. guajava/PE), and 2334 (P. granatum/PE). The disease indexes found in these isolates were $14.24,12.25,11.13$, and $9.10 \%$, respectively. The six remaining isolates, which exhibited the lowest disease indexes, compose the fourth group. Isolates 2336 (E. uniflora/PE), 2547 (P. guajava/PE), 3923 (water from Capibaribe River-PE), 3882 (Passiflora sp/PE), 2680 (Passiflora sp/PE), and 2060 (C. nucifera/PE) showed disease indexes of $7.39,6.41,5.85,5.22,3.78$, and $2.68 \%$, respectively. 


\begin{tabular}{|c|c|}
\hline Isolate & Disease index (\%) \\
\hline 4627 & $100.00^{\mathrm{a}}$ \\
\hline 4626 & $42.27^{b}$ \\
\hline 4629 & $34.33^{\mathrm{bc}}$ \\
\hline 4628 & $28.81^{\text {bed }}$ \\
\hline 2543 & $14.70^{\text {bcd }}$ \\
\hline 2980 & $14.24^{\text {cde }}$ \\
\hline 2018 & $12.25^{\mathrm{de}}$ \\
\hline 2335 & $11.13^{\mathrm{de}}$ \\
\hline 2334 & $9.10^{\text {de }}$ \\
\hline 2336 & $7.39^{\mathrm{e}}$ \\
\hline 2547 & $6.41^{\mathrm{e}}$ \\
\hline 3923 & $5.85^{\mathrm{e}}$ \\
\hline 3882 & $5.22^{\mathrm{e}}$ \\
\hline 2680 & $3.78^{\mathrm{e}}$ \\
\hline 2060 & $2.68^{\mathrm{e}}$ \\
\hline
\end{tabular}

As for the experiment of pathogenicity in onion bulbs (Table 5), only onion isolates $4627,4629,4628$, and 4626 were capable of causing lesions and thereby classified as grade 4 (highly pathogenic). Through analysis of the severity of the interactions, four groups with significant differences were defined. The disease indexes did not differ significantly among isolates 4627, 4629 and 4628 (95.83, 91.67 and $91.67 \%$, respectively). The isolate 4626 showed a significantly lower disease index, when compared to the last group (72.92\%).

\begin{tabular}{lc}
\multicolumn{2}{c}{ Table 5. Disease index of four Colletotrichum gloeosporioides isolates, regarding pathogenicity in onion bulbs. } \\
\hline Isolate & Disease index (\%) \\
\hline 4627 & $95.83^{\mathrm{a}}$ \\
4629 & $91.67^{\mathrm{a}}$ \\
4628 & $91.67^{\mathrm{a}}$ \\
4626 & $72.92^{\mathrm{b}}$ \\
\hline
\end{tabular}

$\mathrm{CV}=5.42 \%$. Means followed by the same letter do not differ statistically according to the Tukey test at the $5 \%$ level of probability.

By comparing the two pathogenicity tests, it was observed that all 15 isolates were pathogenic to onion leaves, regardless of the host or the sampling locality, and differed in the disease index. From the four isolates obtained from onion, four were among the most pathogenic $(4627,4626,4629$, and 4628). This result indicates the potential for cross-infection of C. gloeosporioides isolates, as previously shown by other authors for different hosts of this fungus in tropical and subtropical regions (Alahakoon et al., 1994; Freeman and Shabi, 1996; Xiao et al., 2004). Nevertheless, in the tests performed with onion bulbs, only these last four isolates caused lesions, thus showing evidence of host specificity in this case. Fernandes et al. (2002) analyzed 34 C. gloeosporioides isolates from different municipalities in the State of Rio de Janeiro, obtained from naturally infected fruits of the "jiloeiro", bell pepper and eggplant. They tested the pathogenicity of the isolates in the three Solanaceae by inoculation of fruits and plantlets and also found pathogenic specificity to the host species.

Differences found in the two tests suggest that they complement each other, although the test conducted in the leaves seems more suited for the evaluation of the effect in onion production and the test conducted in onion bulbs for the evaluation of its effect on commercial 
quality of the product. Using isolates of C. gloeosporioides from guava cultures, Andrade and Ducroquet (1998) also observed differences in the method of inoculation - plant apex, leaf and fruit - and highlighted the importance of this factor in the evaluation of pathogenicity. In the present study, onion isolates showed pathogenicity in both tests used, regardless of the isolation point in the plant. Furtado et al. (1999), in their study of the pathogenicity of $C$. gloeosporioides isolates obtained from leaves and flower stems of rubber trees from the States of São Paulo, Minas Gerais and Maranhão, demonstrated that through inoculation of rubber tree plantlets the isolates from São Paulo and Minas Gerais were all pathogenic, regardless of the collection point in the plant.

From the 39 arbitrary primers of the OPW, OPA and OPX kits, only the OPA 2 (TGCCG AGCTG), OPA 3 (AGTCAGCCAC), OPW 8 (GACTGCCTCT), OPW 17 (GTCCTGGGTT), OPW 0 (TGTGGCAGCA), OPX 4 (CCGCTACCGA), and OPX 13 (ACGGGAGCAA) were selected for yielding amplifications with a reasonable number of bands, high definition and reproducibility.

The dendrogram obtained from the cluster analysis of RAPD data (Figure 1) evidenced high genetic variability. According to Assunção et al. (1999), this technique is of great use for evaluating variability in species of the genus Colletotrichum. The high genetic variability in species of the genus Colletotrichum was also observed by Martinez-Culebras et al. (2002) when using RAPD. In their study, it was possible to distinguish 15 isolates of $C$. fragariae and eight of $C$. gloeosporioides, collected from strawberry.

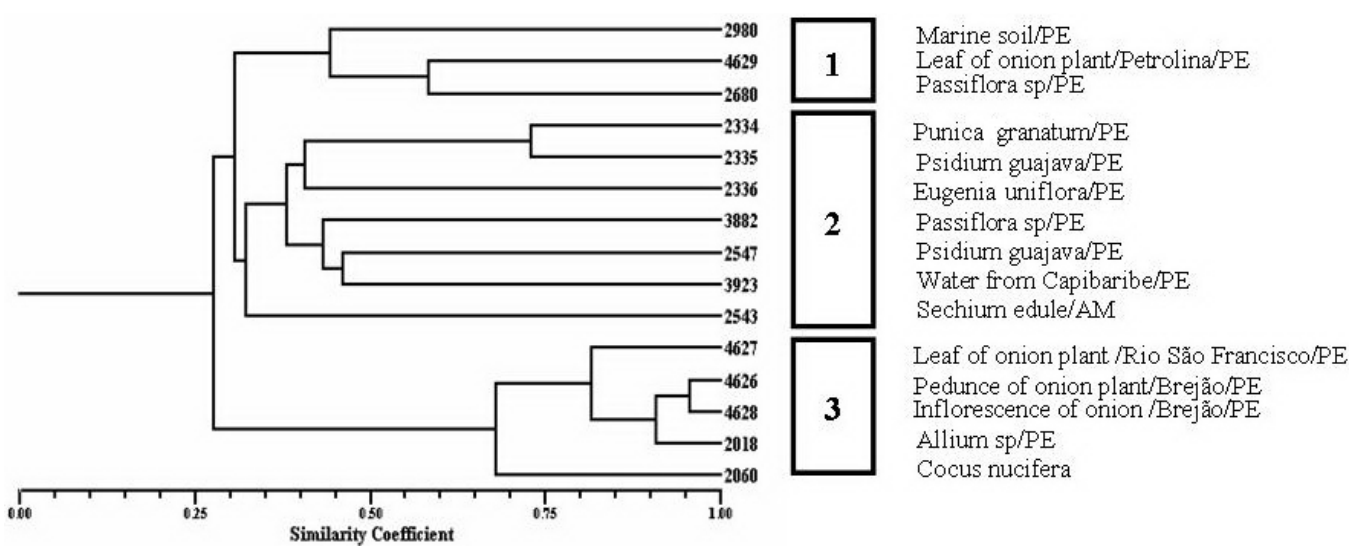

Figure 1. UPGMA dendrogram, based on Jaccard's coefficient, of the 15 Colletotrichum gloeosporioides RAPD profiles.

Three distinct groups were portrayed with ca. $28 \%$ shared fragments. The first group comprises three isolates: 2980 (marine soil-PE), 4629 (onion leaf/Petrolina-PE) and 2680 (Passiflora sp/PE), sharing 45\% fragments with the second group. The second group is composed of seven isolates: 2334 (P. granatum/PE), 2335 (P. guajava/PE), 2336 (E. uniflora/PE), 3882 (Passiflora sp/PE), 2547 (P. guajava/PE), 3923 (water from Capibaribe River/PE), and the isolate 2543 (S. edule/AM), which is clearly distinguished from all others in this group. The third group is composed of five isolates, four of which were obtained from onion plants. Isolate 4627 (onion leaf/Vale do Rio São Francisco, PE) showed 82\% similarity to isolate 4626 (onion peduncle/Brejão, PE); isolates 4628 (onion inflorescence/Brejão-PE) and 4626 
exhibited ca. 96\% similar fragments; isolate 2018 (Allium sp/PE) showed 87\% similar fragments compared to the isolates in the group, and isolate 2060 (C. nucifera/PE) showed fragments $68 \%$ similar to those of the other isolates.

It can be observed that most onion isolates belong to the third group and show high similarity of band patterns among each other, except for isolate 4627, which belongs to group 1 .

In the dendrogram yielded by RAPD, isolates that were extremely aggressive to onion leaves and bulbs grouped with non-aggressive isolates, and therefore, pathogenicity was not decisive in group formation. Munaut et al. (2002) studied the genetic diversity of C. gloeosporioides isolates and their pathogenicity in Stilosantes spp. The isolates were named type A (Stilosantes spp isolates obtained from Mexico and Australia) and type B (Stilosantes guianiensis isolates from Mexico and Africa). A 60\% similarity in type A group and a 30\% similarity in type B group were demonstrated. Also, there was a relationship between groups and pathogenicity, as type A isolates were more aggressive to their host. Gupta et al. (2010) studied eight primers on the genome of C. gloeosporioides isolates collected from different locations. The fingerprints generated were evaluated for overall clearness of banding pattern. Primers OPA-1, OPA-3 and OPA-18 were chosen because they reliably and reproducibly detected polymorphisms among the selected isolates.

The amplification of the ITS1-5.8s-ITS2 locus generated a single fragment of approximately $600 \mathrm{bp}$ for all C. gloeosporioides isolates on agarose gel. Vinnere et al. (2002), analyzing the ITS1-5.8s-ITS2 region, managed to determine that the species $C$. acuntatum, $C$. gloeosporioides and $C$. dematium, among the isolates identified in the classic fashion, were actually $C$. gloeosporioides, thus demonstrating that this technique is highly indicated for interspecific analysis.

In the analysis of the restriction fragments from the amplification products, the absence of restriction sites for DraI enzyme was observed. Digestion with HaeIII enzyme yielded monomorphic 300-bp fragments for the 14 isolates from the State of Pernambuco and 400- and 200-bp fragments for the 2543 isolate from the State of Amazonas, distinguishing it from the others. With MspI digestion, 12 isolates (2980, 4627, 4628, 4629, 2018, 2334, 2335, 2336, $3882,2543,4626,2060$ ) exhibited 300-bp fragments, and isolates 2680, 2547 and 3923 produced 350-, 100-, and 50-bp fragments, respectively.

Cluster analysis of the restriction fragments from the amplification products of the rDNA ITS region with HaeIII and MspI together (Figure 2) showed the existence of three distinct groups. The first group comprises 11 identical isolates: 2980 (marine soil-PE), 4627 (onion leaf/Vale do Rio São Francisco), 4626 (onion peduncle/Brejão/PE), 4628 (onion inflorescence/Brejão, PE), 3882 (Passiflora sp/PE), 2336 (E. uniflora/PE), 2335 (P. guajava/PE), 2334 (P. granatum/PE), 2060 (C. nucifera/PE), 4629 (onion leaf/PetrolinaPE), and 2018 (Allium $\mathrm{sp} / \mathrm{PE}$ ). All onion isolates are found in this group. The second group is composed of three isolates: 2680 (Passiflora sp/PE), 2547 (P. guajava/PE) and 3923 (water from Capibaribe River, PE), showing $24 \%$ similarity to the first group and $26 \%$ similarity to the third group. The third group is composed solely of the Amazonas isolate, 2543 (S. edule/AM), and showed ca. $26 \%$ similarity to the first and second groups.

Saha et al. (2002), through the restriction of fragments from the ITS region, evaluated the Colletotrichum species that caused lesions in Hevea brasiliensis. It was possible 


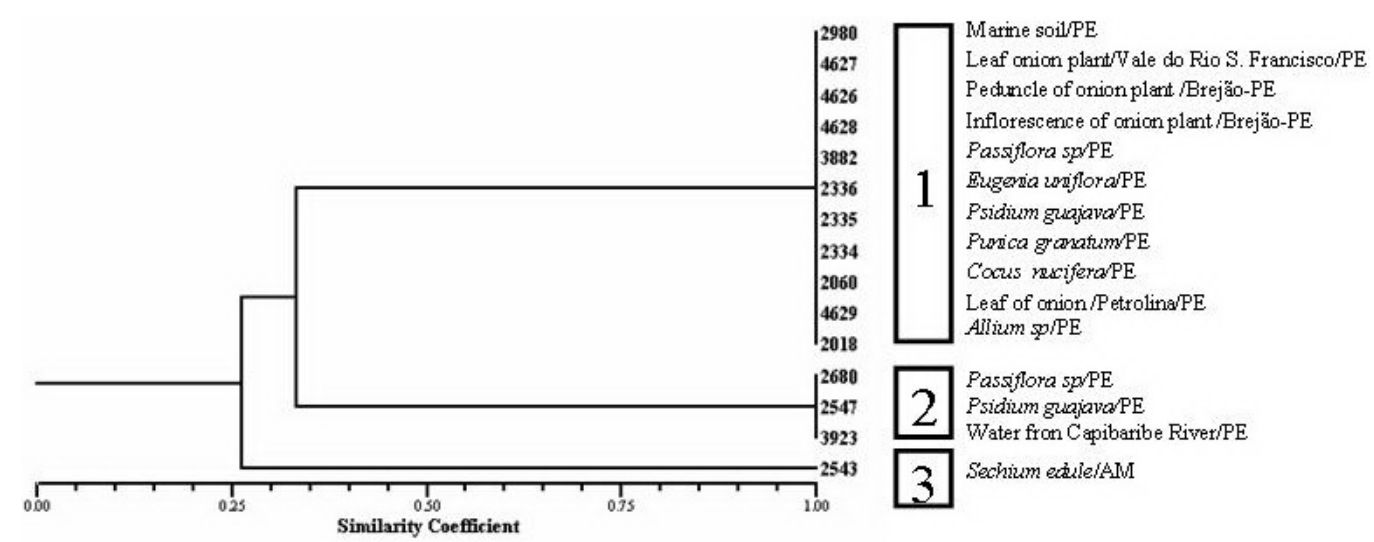

Figure 2. UPGMA dendrogram, based on Jaccard's coefficient, of the 15 Colletotrichum gloeosporioides restriction profiles of the amplified fragment of rDNA ITS with restriction enzymes HaeIII and MspI.

to observe the grouping of species that caused larger lesions. In the present study, analysis of restriction fragments from the rDNA ITS region did not show grouping of the isolates most pathogenic to onion.

\section{AKNOWLEDGMENTS}

\section{Research supported by CNPq.}

\section{REFERENCES}

Abang MM, Winter S, Green KR, Hoffmann P, et al. (2002). Molecular identification of Colletotrichum gloeosporioides causing yam anthracnose in Nigeria. Plant Pathol. 51: 63-71.

Afanador-Kafuri L, Minz D, Maymon M and Freeman S (2003). Characterization of Colletotrichum isolates from Tamarillo, Passiflora, and Mango in Colombia and identification of a unique species from the genus. Phytopathology 93: 579-587.

Alahakoon PW, Brow A and Screenivasaprad S (1994). Cross-infection potential of genetic groups of Colletotrichum gloeosporioides on tropical fruits. Physiol. Mol. Plant Pathol. 44: 93-103.

Andrade ER and Ducroquet JPH (1998). Comparação de diferentes métodos de inoculação de Colletotrichum gloeosporioides em goiabeira serrana. Fitopatol. Bras. 23: 486-488.

Assunção IP, Alfenas AC, Coelho RSB and Lima GSA (1999). Análise isoenzimática de isolados de Colletotrichum gloeosporioides, agente etiológico da antracnose foliar da cebola. Summa Phytopathol. 25: 293-298.

Azedo JL (1998). Genética de Microrganismos. ABDR, Goiânia.

Barbosa MPM (2001). Variabilidade patogênica de Colletotrichum graminicola isolado de milho (Zea mays L.). Master's dissertation, Escola Superior de Agricultura Luiz de Queiroz, Piracicaba.

Cenkci S, Yildiz M, Cigerci IH, Konuk M, et al. (2009). Toxic chemicals-induced genotoxicity detected by random amplified polymorphic DNA (RAPD) in bean (Phaseolus vulgaris L.) seedlings. Chemosphere 76: 900-906.

Djadid ND, Gholizadeh S, Aghajari M, Zehi AH, et al. (2006). Genetic analysis of rDNA-ITS2 and RAPD loci in field populations of the malaria vector, Anopheles stephensi (Diptera: Culicidae): implications for the control program in Iran. Acta Trop. 97: 65-74.

Fernandes MCA, Santos AS and Ribeiro RLD (2002). Adaptação patogênica de isolados de Colletotrichum gloeosporioides obtidos de frutos de jiloeiro, pimentão e berinjela. Summa Phytopathol. 28: 325-330.

Franck A and Jha AN (2006). The random amplified polymorphic DNA (RAPD) assay and related techniques applied to genotoxicity and carcinogenesis studies: a critical review. Mutat. Res./Rev. Mutat. Res. 613: 76-102.

Freeman S and Shabi E (1996). Cross-infection of subtropical and temperate fruits by Colletotrichum species from various 
hosts. Physiol. Mol. Plant Pathol. 49: 395-404.

Fungaro MHP (2000). PCR na micologia. Biotec. Cien. Desenvol. 20: 12-16.

Furtado EL, Bach EE, Kimati H, Menten JOM, et al. (1999). Caracterização morfológica, patogênica e isoenzimatica de isolados de Colletotrichum gloeosporioides de seringueira. Summa Phytopathol. 25: 222-228.

Gupta VK, Pandey A, Kumar P, Pandey BK, et al. (2010). Genetic characterization of mango anthracnose pathogen Colletotrichum gloeosporioides Penz by random amplified polymorphic DNA analysis. Afr. J. Biotech. 26: 4009-4013.

IBGE (1999). Produção Agrícola Municipal. Culturas Temporárias e Permanentes, Brasil.

Mackinney RH (1923). Influence on soil temperature and moisture on infection of wheat seedling by Helminthosporium sativus. J. Agric. Res. 26: 195-218.

Manonmani A, Townson H, Adeniran T, Jambulingam P, et al. (2001). rDNA-ITS2 polymerase chain reaction assay for the sibling species of Anopheles fluviatilis. Acta Trop. 78: 3-9.

Maranhão EHA, Candeia JA, Maranhão EAA, Menezes D, et al. (1997). Avaliação e intervalos de aplicação de fungicida no controle do "Mal-das-sete-voltas" em cebola. Pesq. Agropec. Bras. 10: 39-43.

Martinez-Culebras PV, Barrio E, Suarez-Fernandez MB, Garcia-Lopez MD, et al. (2002). RAPD analysis of Colletotrichum species isolated from strawberry and the design of specific primers for the identification of C. fragariae. $J$. Phytopathol. 150: 680-686.

Martinez-Culebras PV, Querol A, Suarez-Fernandez MB, Garcia-Lopez MD, et al. (2003). Phylogenetic relationships among Colletotrichum pathogens of strawberry and design of PCR primers of their identification. J. Phytopathol. 151: 135-143.

Munaut F, Hamaide N and Maraite H (2002). Genomic and pathogenic diversity in Colletotrichum gloeosporioides from wild native Mexican Stylosanthes sp., and taxonomic implication. Mycol. Res. 106: 579-593.

Raeder U and Broda P (1985). Rapid preparation of DNA from filamentous fungi. Lett. Appl. Microbiol. 1: 20.

Rholf FJ (1988). NTSYS-PC Numerical Taxonomy and Multivariate Analysis System. Applied Biostatistics Inc. Exeter Publishing, New York.

Saha T, Kumar A, Ravindran M, Jacob CK, et al. (2002). Identification of Colletotrichum acutatum from rubber using random amplified polymorphic DNA and ribosomal DNA polymorphisms. Mycol. Res. 106: 215-221.

Stummer BE, Zanker T, Scott ES and Whisson DL (2000). Genetic diversity in populations of Uncinula necator: comparisons of RFLP and PCR-based approaches. Mycol. Res. 104: 44-52.

Vinnere O, Fatehi J, Whright SA and Gerhardson B (2002). The causal agent of anthracnose of Rhododendron in Sweden and Latvia. Mycol. Res. 106: 60-69.

White TJ, Bruns T, Lee S and Taylor J (1990). Amplification and Direct Sequencing of Fungal Ribosomal RNA Genes for Phylogenetics. In: PCR Protocols, a Guide to Methods and Applications (Innis MA, ed.). New York Academic Press, New York, 315-322.

Xiao CL, Mackenzie SJ and Legard DE (2004). Genetic and pathogenic analyses of Colletotrichum gloeosporioides isolates from strawberry and noncultivated hosts. Phytopathology 94: 446-453. 